\title{
Integral Analysis of Cognitive Motor Skills and the Social Dimension of Sport: Approach to Sports Initiation and School Sports
}

\author{
Vélez-Meza Edda ${ }^{1, *}$, Méndez-Urresta Jacinto ${ }^{2}$, Vargas-Chagna Johanna ${ }^{3}$, Flores-Torres Diego ${ }^{4}$ \\ ${ }^{1}$ Universidad Técnica del Norte, Postgraduate Institute, Master Programme in Technology and Educational Innovation, Av. 17 de Julio \\ y José Córdoba 5-21, Ibarra, EC 100105, Ecuador \\ ${ }^{2}$ Universidad Técnica del Norte, Health Sciences Faculty, Physical Therapy Career, Av. 17 de Julio y José Córdoba 5-21, Ibarra, EC \\ 100105, Ecuador \\ ${ }^{3}$ Universidad Técnica del Norte, Education Science and Technology Faculty, Av. 17 de Julio y José Córdoba 5-21, Ibarra, EC 100105, \\ Ecuador \\ ${ }^{4}$ Instituto Superior Tecnológico Cotacachi, Superior Technology in Textile Confection, Waminka Rumiñahui s/n, sector San Teodoro, \\ Santa Ana de Cotacachi, EC 100301, Ecuador
}

Received December 22, 2020; Revised February 24, 2021; Accepted March 16, 2021

\section{Cite This Paper in the following Citation Styles}

(a): [1] Vélez-Meza Edda, Méndez-Urresta Jacinto, Vargas-Chagna Johanna, Flores-Torres Diego , "Integral Analysis of Cognitive Motor Skills and the Social Dimension of Sport: Approach to Sports Initiation and School Sports," International Journal of Human Movement and Sports Sciences, Vol. 9, No. 3, pp. 495 - 502, 2021. DOI: 10.13189/saj.2021.090315.

(b): Vélez-Meza Edda, Méndez-Urresta Jacinto, Vargas-Chagna Johanna, Flores-Torres Diego (2021). Integral Analysis of Cognitive Motor Skills and the Social Dimension of Sport: Approach to Sports Initiation and School Sports. International Journal of Human Movement and Sports Sciences, 9(3), 495 - 502. DOI: 10.13189/saj.2021.090315.

Copyright $\mathrm{C} 2021$ by authors, all rights reserved. Authors agree that this article remains permanently open access under the terms of the Creative Commons Attribution License 4.0 International License

\begin{abstract}
Cognitive-motor skills and the social dimension of sports games are relevant factors in sports initiation. The research aimed to analyze the theoretical-practical mastery of the cognitive, motor and social abilities of the game and its compliance in sessions by the basketball and football coaches of Imbabura. As well as establishing the relationship of the skills developed by sports children with coaches who have a traditional teaching approach versus those with a formative focus on sports initiation. The research is descriptive-observational, mixed and transversal. The survey and participatory observation were applied to 12 coaches. It shows that most teachers have little information about the skills and dimensions that the sport develops at the initiation stage. Participatory observation of the indicators of motor skills and the social dimension of the game is carried out in a high and medium degree by the coaches. Indicators of cognitive abilities were achieved to a limited and medium degree by coaches. Motor and social skills show greater development in the practice of children's play and sport to the detriment of cognitive abilities. The Wilcoxon Mann
\end{abstract}

Whitney Test for each of the game's skills and dimensions chronicles that the strata of trainers with a traditional approach have a higher score on motor skills, while cognitive skills and social dimension have a lower score compared to the training focus coach. It is concluded that the development of the game's abilities and dimensions depends significantly on the approach to teaching sports initiations that coaches have.

Keywords Sports Game, Cognitive and Motor Skills, Social Dimension, School Sports Initiation

\section{Introduction}

The article highlights the need to reflect on the interdependence of cognitive and motor abilities in sports games with the social dimension manifested in the initiation of collective sports. Blázquez considers it necessary to determine the pedagogical conditions that 
make it possible to turn sport into an educational activity, guided by the principle "to start sporting games through the game itself"(1).

Play in sport is an educational tool that benefits the integral development of the human being, favors psychomotor abilities, promotes affective, cognitive and social aspects of an individual (2), (3), (4), (5), (6) y (7). Sports play an indispensable resource in sports initiation as a learning situation related to educational intentions and as a didactic tool due to its motivating nature, in addition to promoting motor improvement, values and socio-affective relationships (8).

The cognitive social theory, formulated by Bandura (9), (10), (11) and which focuses on the expectations and values that individuals confer on different goals and execution activities, is assumed. Consider the criteria by which subjects judge their competence and why they define achievement success or failure (sport), mastery goals (task), and competitiveness goals (ego). Sports-oriented subjects perceive it as an activity that strengthens cooperation, social responsibility and the learning of sports skills, complying with rules and improving health. On the other hand, the subjects oriented towards the ego perceive the activity as a system of education for life in society, acquire greater social status, increase popularity and achieve economic wealth.

Regarding the theory (12) it emphasizes that the athlete in any situation makes a series of cognitive associations that depend on various factors (individual, social, environmental) and that make a situation be perceived as positive, negative or neutral. Sports games present a wide variety of motor situations in which the athlete should not limit himself to wondering how he should do it, but also what, when and why. Therefore, it is important to ask oneself about the motor challenges and unique characteristics that sports present: What type of cognitive and motor responses most effectively solve game situations? (13).

Authors such as (14), (15), (16) and (17) consider play as the most important learning tool for the child in the early ages. Additionally, (18) it raises the motor capacities (perception and motor response), cognitive capacities (observation, analysis and interpretation of the different situations) and social dimension (appearance of affective bonds, social learning and discovering the other), with the purpose of achieving the function to be assigned to collective sports.

In this framework, motor training plays a fundamental role in the sports initiation stage, which seeks to make better use of cognitive abilities, through sensory-motor and perceptual-motor experiences, which help the child to adapt and interrelate with the environment (19). The global, nonspecific and multipurpose learning of these abilities must be conceived as the way to connect in a progressive and effective way, the general motor skills typical of previous stages with the beginning of the learning of the elements that make up a specific sport (20).

In collective sports, due to the characteristics of the cooperation-opposition game, there is a high degree of perceptual-motor involvement, related to the knowledge of the functional structure and necessary skills in a sports specialty, where a subject has character experiences and experiences. cognitive and motor (21). These sports learnings contribute significantly to children's physical activity levels (22). Perception is defined as the ability to understand the meaning of situation, key factor of motor competition (7).

Perceptual skills comprise body perception and temporal space perception, which involves motor activities and activities related to location and orientation in space (23). The perception will allow the child athlete to detect all the information necessary for a good execution, to combine the technique according to the tactic, to administer force and speed requirements to correctly execute the sports movements (24). The interrelation between perceptual input and motor execution refers to the technical-tactical dimension in the context of the game and has an intention in the training of the athlete, which must be incorporated by the teacher-coach as a methodological strategy in his teaching plan.

The cognitive and motor mechanisms related to perception are enriched and expanded with the possibility of transferring learning, through sports games for understanding, characterized by tactical awareness and decision-making for correct execution (17). Authors like (25), (26) and (27) consider that playing successfully implies knowing the reality of the game, requires observing colleagues and opponents, identifying behaviors and interpreting them with the aim of deciding what is most convenient; the player must analyze the problematic situations at all times to look for possible solutions.

The development of cognitive strategies in sports initiation involves elementary training in psychomotor skills, technical acquisition, knowledge of the game and its rules; in a second moment it corresponds to the development of tactical capabilities by observing various game situations, favoring the tactical and creative thinking of the athlete nobel.

The social dimension of the game refers to the behavioral, attitudinal, socio-affective and volitional learning that will become evident in individual and collective physical-sports practices. Education through play plays a fundamental role in acquiring affective and relational skills necessary for life in society (28), (29), (17), (30) y (14). Sports play constitutes an important strategic contribution to consolidate the child's personality, which contributes to the development of exercise culture and specialized motor intelligence, aspects that will allow him to solve life problems.

Coaches must analyze sports play as social construction, have mastery of interpersonal and social skills, which allows them to promote the recreational aspects of sport 
and be able to maintain interest in initiation athletes (31), (32).

Sports initiation is the child's first encounter with sport where the first impressions of liking, liking, rejection, pleasure, motivation are established in the face of carrying out a certain sports discipline. Sports initiation is any teaching-learning process, where the athlete must evolve through a series of stages of learning and development of various contents (physical, technical, tactical or psychological) adapted to both their biological and psychological characteristics (14).

Traditionally, sports initiation has been associated with the moment in which the child begins specific learning and practices one or more sports (general motor approach towards performance), unfortunately the society of sports consumption requires early sports specialization (33). The learning process is totally decontextualized, it seeks the maximum degree of the technique in a mechanized way (17).

The proposal of a new approach highlights the pedagogical action in the initiation process to individual or collective sports, refers to the versatility compared to the specialty, considers the characteristics of the child and the coeducational process in attitudes, norms and values. It uses play as a means of training, especially at an early age according to (25), it focuses on the athlete learning and mastering the task progressively, it supposes an increase in motivation in children, active participants in activities develop, contributes to integral development and favors multidisciplinary work (17).

Sports initiation should focus on sport as a healthy and recreational activity, based on the pleasure of movement, on the satisfaction of personal and collective effort, where competition is a means and results a part of the incentive of your own game (25) (18) y (1). In addition, (28) the game stands out in sports initiation as a means of communication and personal expression, children express their feelings, their emotions and their character. Sports play requires, in its realization, to put into action all the motor, cognitive, affective and social skills and abilities of the initiating athlete. For this reason, this study aims to analyze the theoretical-practical mastery of the cognitive, motor and social abilities of the game and its compliance in sessions by coaches of children's categories. In this way, to answer research questions: What level of specific information about the skills and dimensions of the game in the initiation to collective sports have coaches? What are the motor and social skills with the greatest development in the practice of children's play and sport? And what skills do teachers with a traditional teaching approach versus those with a formative approach develop in students?

\section{Methodology}

\section{Respondent typology}

It is an investigation with a mixed approach, of a transversal, descriptive and observational type (16). A sample of 12 basketball and football coaches was selected in the 10-12-year-old category of Imbabura province, which represents $28.57 \%$ of the population. who applied a survey and a direct and participant observation sheet, prior to their informed consent. The observation was made during the training sessions. The trainers participating in the research were: $100 \%$ male, $40 \%$ are between 36 and 40 years old, considering a range of 31 to 45 years in proportional cumulative ratio, $80 \%$ of the sample is represented in this age range.

\section{Analysis of the theoretical-practical dominance of the cognitive, motor and social abilities of the game by the coaches of the category of children of basketball and football}

To identify the theoretical-practical knowledge of cognitive-motor capacities and indicators and the social dimension of sports play, a survey was applied, consisting of 12 closed questions with a 4-level Likert scale, in order to analyze aspects related to the degree of knowledge and importance of the application of sports games, as well as the formative aspects of the game for learning and initiation of collective sports, grouped into 2 dimensions: D1. Theoretical domain of training and D2. Capabilities and dimension of the game.

The instrument was validated by experts in children's physical activity and sports initiation. The data processing is carried out with the statistical software $\mathrm{R}$ version 3.6.2 (The R Project for Statistical Computing).

The rubric used in the observation sheet indicates the fulfillment of the indicators of the capabilities and dimensions of the game (Table 1). 
Table 1. Observation Sheet Rubric

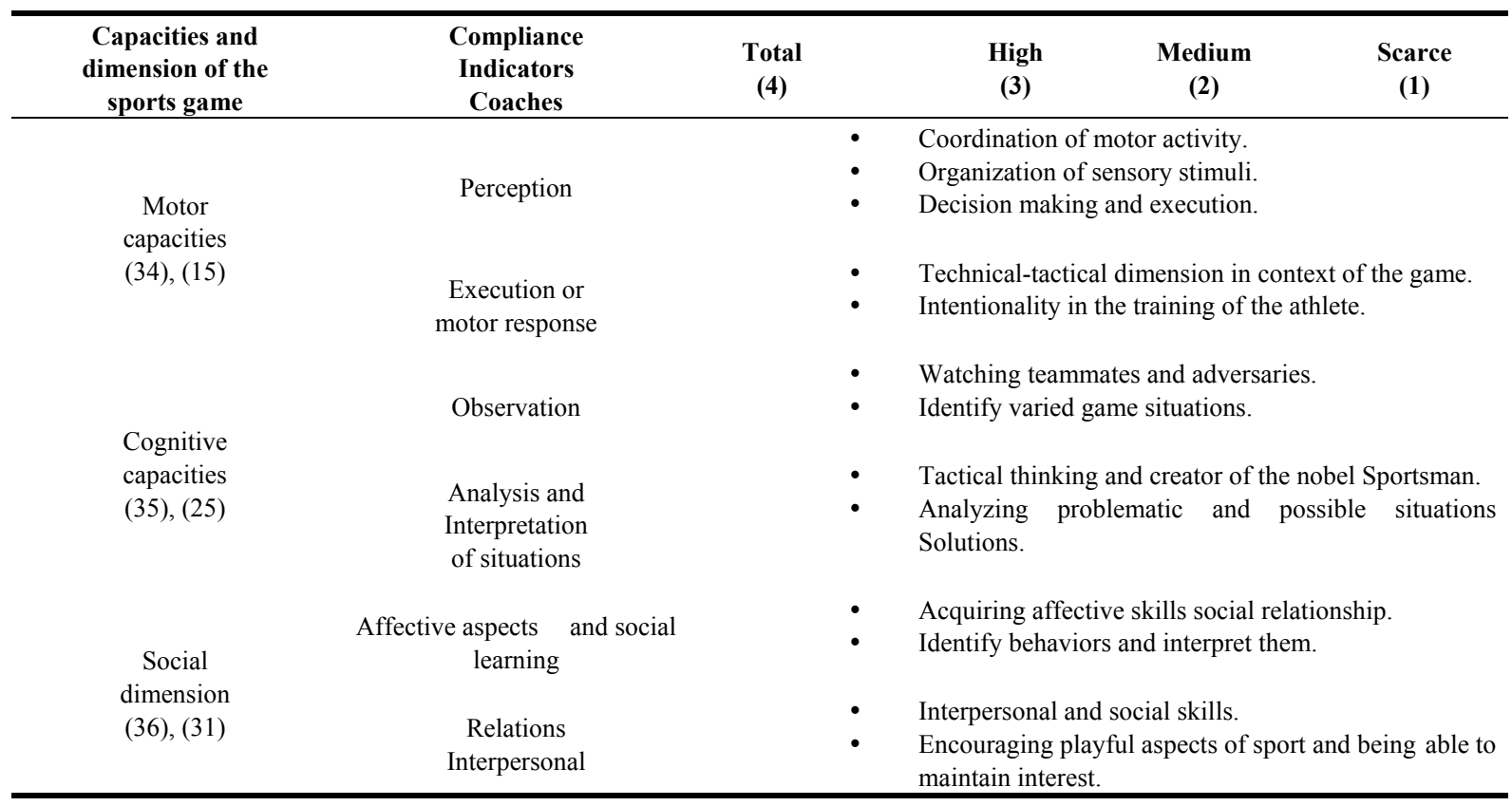

\section{Result}

The results are organized in two sections: First, the theoretical domain and training of the coaches of the infantile category on the cognitive-motor abilities and social dimension of sports play are described, and the second, shows the results of compliance with the indicators of the capabilities implemented in the training sessions.

Results on the theoretical-practical domain of the cognitive, motor and social capacities of the game and its fulfillment in the sessions by the coaches of basketball and children's soccer

The results will be presented by dimensions:

D1. Theoretical domain and training. With reference to the importance and level of knowledge, $84 \%$ of the coaches consider the application of sports games as a learning strategy very important and affirm that they have good knowledge about the abilities and dimensions of the game at the beginning collective sports. Authors like (7), (8), (15) and (17) highlight sports games as a valuable educational resource in the children's sports stage. This supposes the correct preparation of sports professionals to achieve the accepted initiation of children in sports disciplines (20). These results must be evidenced in the praxis of the teaching plans of the teacher-coaches.

Respondents consider that training by sports organizations in sports initiation issues is not very relevant, as $58 \%$ express it. Sports play as an educational and integral development element of the small athlete is sometimes used by $66 \%$ of coaches. These data coincide with (20), who obtained low results on the level of preparation of sports professionals, highlighting the main causes: poor preparation of sports managers, poor organization of the process, insufficient theoretical-methodological work. It is necessary that sports organizations and coaches assume continuous training as a fundamental factor of optimal performance, and that it is reflected in adequate training processes in the initiation of collective sports.

D2. Capabilities and dimension of the game. Only $50 \%$ of coaches affirm sports play as a learning strategy and develop motor skills in collective sports. The same percentage $(50 \%)$ point to the execution and motor response as an indicator of the abilities that are developed in the sports game. The traditional approach is evident, since valuable aspects such as the social dimension and the cognitive capacity of the game are relegated. Coaches should use sports play for both social construction and mastery of interpersonal and social skills, which will enable them to foster playful aspects of sport and be able to maintain interest in initiating athletes (31).

\section{Results on the fulfillment of cognitive-motor abilities and social dimension of sports games implemented in training sessions}

In the observation of motor capacity indicators (Table 2), $58 \%$ of the coaches highly comply with the motor execution-response capacity and the other $42 \%$ register medium compliance with the perception indicator. The perception will be the fruit of a complex work of analysis and synthesis and will allow to capture information on complete situations in the execution of the training sessions of collective sports (24).

Regarding the indicators of cognitive abilities (Table 2), $42 \%$ of coaches comply with observation in medium grade; 
$50 \%$ comply to a limited extent with the analysis and interpretation of situations. The didactic proposals must incorporate the reflection and analysis of what is happening and the creation of strategies to facilitate the transfer of knowledge from other situations (8).

Observation of indicators of the social dimension (Table 2), determines that interpersonal relationships are fulfilled to a high degree with $50 \%$ of the coaches observed, while affective aspects and social learning were fulfilled in medium degree by the other $50 \%$. The sports-educational game must be oriented to develop social values, depending on the affective component especially of team sports (25), (36).

To verify if the data is parametric, the Shapiro Normality Test was carried out in the R software for each of the capacities and dimensions of the game, obtaining for the motor capacities a $\mathrm{p}$-value $=0.2134$, cognitive capacities $\mathrm{p}$-value $=0.1122$ and social dimension $\mathrm{p}$-value $=0.1703$; that is in the null's retention zone (37) and the normality assumption cannot be accepted.

The hypotheses that were formulated in all cases were:

- H1: The development of the game's motor, cognitive and social dimensions depend significantly on the teaching approach of sports initiation that coaches possess.

- H0: The development of the game's motor, cognitive and social dimensions skills do not depend significantly on the approach to teaching sports initiation that coaches possess.

To verify equality of variances, a box diagram is made of each of the capabilities and dimensions of the game (Fig. 1) in relation to the approach to sports initiation (traditional, formative).

The graphs show that the assumption of homogeneity (equality of variances) cannot be accepted, so the Wilcoxon Mann Whitney Test (37) is applied to demonstrate the difference between the means, obtaining a $\mathrm{p}$-value for the motor capacities. $=0.02044$, cognitive abilities $\mathrm{p}$-value $=0.03563$ and social dimension $\mathrm{p}$-value $=$
0.01186; therefore, the alternative hypothesis that there is a difference in the scores of the capacities and dimensions of the game between the strata of the coaches with a traditional and formative approach in sports initiation is accepted. Therefore, it can be concluded that coaches with a traditional approach have a higher score in motor skills, while cognitive abilities and a social dimension have a lower score compared to that of a formative approach.

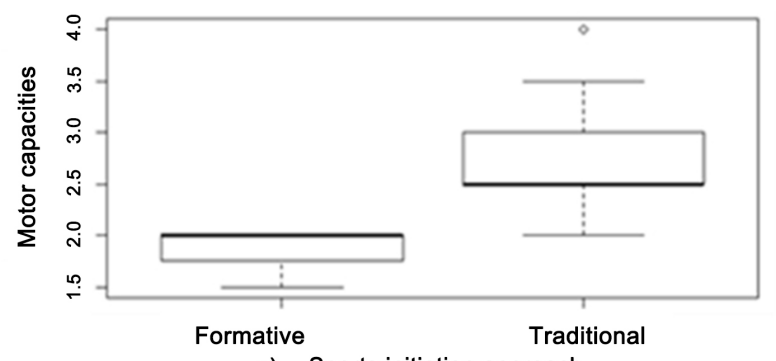

a) Sports initiation approach

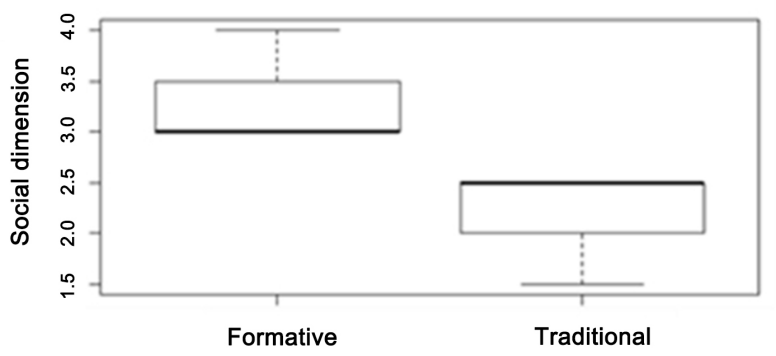

b) Sports initiation approach

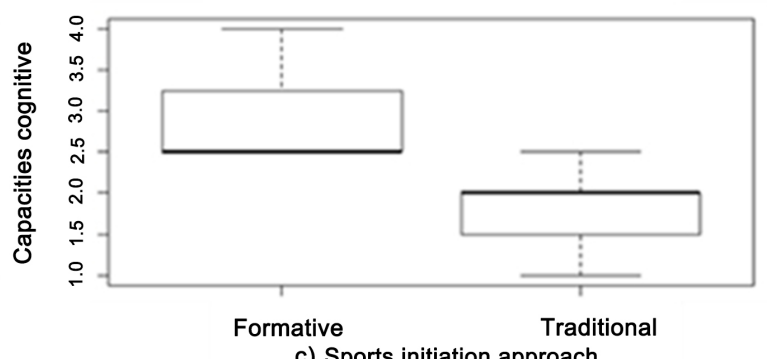

Figure 1. Boxplot: a) Motor capacities, b) Social dimension and c) Cognitive capacities

Table 2. Distribution of cognitive-motor skills and social dimension of sports games implemented in training sessions

\begin{tabular}{|c|c|c|c|c|c|}
\hline $\begin{array}{c}\text { Capacities and } \\
\text { dimension of the sports }\end{array}$ & $\begin{array}{l}\text { Compliance } \\
\text { Frequency }\end{array}$ & $\begin{array}{c}\text { Total } \\
\% \\
\end{array}$ & $\begin{array}{c}\text { High } \\
\% \\
\end{array}$ & $\begin{array}{c}\text { Medium } \\
\% \\
\end{array}$ & $\begin{array}{c}\text { Scarce } \\
\%\end{array}$ \\
\hline \multirow{2}{*}{ Motor capacities } & Perception & 17 & 17 & 42 & 25 \\
\hline & Execution or motor response & 17 & 58 & 17 & 8 \\
\hline \multirow{2}{*}{ Cognitive capacities } & Observation & 17 & 17 & 42 & 25 \\
\hline & Analysis and interpretation situations & 17 & 17 & 17 & 50 \\
\hline \multirow{2}{*}{ Social dimension } & Affective aspects and social learning & 17 & 17 & 50 & 17 \\
\hline & Relations & 17 & 50 & 17 & 17 \\
\hline
\end{tabular}




\section{Discussion}

Most coaches have little specific information about the motor skills, cognitives and socials dimensions of the game in the initiation to collective sports. These results are contrasted with those obtained by (20), which shown a low behavior in the level of preparation of sports professionals over the process of school sports initiation. It points out as main causes that cause the low level of preparation on the process of school sports initiation: poor preparation existing in sports managers, poor organization of the process, poor theoretical-methodological work carried out for collective sport and insufficient linkage between professor of physical education and the technician of the sports area. The study of (38) shows the influence of the coach's profile and the teaching-learning process on base collective sports. It suggests that coaches should master a wide repertoire of general and specific content, possess a great problem-solving capacity, as well as the design and development of tasks according to the age and level of demands of the competition.

Motor and social skills are more developed in the practice of children's play and sport to the detriment of cognitive abilities. There is evidence to support the correlation between children's sports practice of collective sports and cognitive abilities (attention, decision-making and visual-spatial work memory), which justifies the suggestion of introducing deeper cognitive participation during sports initiation teaching plans (38). The potential development of these skills in sports children could help coaches achieve optimal performance improvement during training sessions (39), (27). Likewise, the social dimension (values, interpersonal and social skills) in team sports should be considered by sports initiation coaches (25), (31), (32), (29). Studies of (40) show that relationships built in training and with the family through sport are important factors for the insertion and maintenance of the young in sport, in addition, strengthens social self-concept (41) .

The strata of trainers with a traditional approach have higher scores on motor skills, while cognitive abilities and social dimension have lower scores compared to those of a formative approach. According to (39) the traditional model of school sport reinforces dominant values in society such as hegemony and competition; satiates only the interests and abilities of those whose skills are consistent with those valued in the field. Under the dominant model, there is little room to work on aspects such as inclusion, gender perspective, autonomy and contact with nature. On the contrary, a training model of school sports must ensure the practice of long-term physical-sports activities, through the integral development of participants, reduction of abandonment rates and non-continuation of practice, creating healthy habits and a widespread welfare state. The authors (40)consider that necessary changes are required in the approach of assessing the performance of the professor of sports initiation, so that the requirement to achieve sports results does not prevail over professional performance. This implies that there must be an adequate balance between the educational component and the instructional component.

The shift of approach can be considered a global, coherent and alternative perspective to the teaching of sports games that arises as a reaction to the traditional system. The study of (41) proposes that formative process in sports initiation requires that the sport be part of physical exercises, healthy improvement, clean competition where man can master his body, use the mind to get the most out of it. To all this, incorporate the constant improvement of the feeling of health, well-being and being in shape. Likewise (42), (43) and (44) highlights the importance of using the pedagogical potential of the game itself in the process of learning motor actions from an innovative approach oriented to creative problem solving. This coincides with the proposal of a formative approach to sports initiation through the pedagogical value of the game.

This study has different limitations among which stand out: that the sample has been limited to a specific context and only with the participation of an actor of those who make up the process of sports initiation.

As future lines of research, the following are proposed:

- Extend the investigation to the agents of the training and sports initiation action.

- Replicate research- action in other contexts, both national and international and with other sports.

- To relate the pedagogical, didactic and scientific foundations and the professional training of coaches.

- Theoretical-practical skills for the development of motors skills, cognitive and social skills of sports gaming.

- Beliefs of the other actors of the sports initiation process (sports children, parents, managers) have regarding the learning teaching process.

\section{REFERENCES}

[1] Méndez-Giménez A, Méndez-Giménez C. Los juegos en el currículum de la Educación Física [Internet]. Barcelona, España: Paidotribo; 2018 [cited 2020 Mar 18]. Available from: https://bit.ly/2UfSsLP

[2] Gallardo-López J, Gallardo-Vázquez P. Teorías sobre el juego y su importancia como recurso educativo para el desarrollo integral infantil. Rev Educ Hekademos [Internet]. 2018 [cited 2020 Mar 18];24:41-51. Available from: https://bit.ly/2WmzMg1

[3] Martínez-Benítez, Jenny; Mendoza-Yépez, Marlene; Ortiz-Bravo N. Influencia del ambiente familiar y escolar en la práctica de la actividad física-deportiva en niños de 9 a 12 años. EmásF Rev Digit Educ física [Internet]. 2017 [cited 2020 Mar 18];47:76-88. Available from: https://bit.ly/2whRUwM

[4] Viciana-Garófano VC-GL. Importancia de la motricidad para el desarrollo integral del niño en la etapa de educación 
infantil. EmásF Rev Digit Educ física [Internet]. 2017 [cited 2020 Mar 18];47:89-105. Available from:https://bit.ly/2U0 yvtf

[5] Bernate, Jayson; Fonseca, Ingrid; Betancourt M. Impacto de la actividad física y la práctica deportiva en el contexto social de la educación superior. Retos [Internet]. 2020 [cited 2020 Mar 18]; 37(37):742-7. Available from: https://bit.ly/33y9Q2G

[6] O’Donnell C, Sandford R, Parker A. Physical education, school sport and looked-after-children: health, wellbeing and educational engagement. Sport Educ Soc. 2019 Jul 20;25(5):1-13.

[7] Arufe-Giráldez V. ¿Cómo debe ser el trabajo de Educación Física en Educación Infantil? Retos nuevas tendencias en Educ física, Deport y recreación [Internet]. 2020 [cited 2020 Mar 18]; 37(37):588-96. Available from: https://bit.ly/2Wp 6u0d

[8] Cañizarez-Márquez, José; Carbonero-Celis C. Deporte Educativo: Su enseñanza en la edad escolar [Internet]. España: Wanceulen Editorial Deportiva S.L.; 2016 [cited 2020 Mar 18]. Available from: https://bit.ly/3965NeN

[9] Dosil J. Psicología de la actividad física y del deporte. Madrid, España: McGraw-Hill; 2004.

[10] Weinberg, Robert; Gould D. Fundamentos de Psicología del Deporte y del Ejercicio Físico [Internet]. Madrid, España: Editorial Médica Panamericana.; 2010 [cited 2020 Mar 18]. Available from: https://bit.ly/33sRsYV

[11] Aguilar-Parra J. Psicología del Deporte Vol 27, nº 1, 2018 [Internet]. España: Revista de Psicología del Deporte; 2018 [cited 2020 Mar 18]. Available from: https://bit.ly/2xL8Jk8

[12] Pesqueira-Leal, L.; Bracho-Marrufo, V.; Gallegos-Sánchez, J.; Villarreal Ángeles M. Perspectivas en la psicología del deporte: Investigación y aplicaciones [Internet]. Universidad Juárez del Estado de Durango; 2018. Available from: https://bit.ly/2IWmleC

[13] Ministerio de Educación de Ecuador. Currículo de los Niveles de Educación Obligatoria: Nivel Bachillerato [Internet]. Ecuador; 2019 [cited 2020 Mar 18]. Available from: www.educacion.gob.ec

[14] Giménez Fuentes-Guerra, Francisco; Díaz-Trillo M. Diccionario de Educación Física Primaria [Internet]. España: Publicaciones de la Universidad de Huelva. ; 2016 [cited 2020 Mar 19]. Available from: https://bit.ly/33ws5Fo

[15] Sánchez-Sánchez, Javier; Pérez-Muñoz, Salvador; Yagüe-Cabezón J. El proceso de Enseñanza-Aprendizaje de los deportes colectivos: Especial referencia al fútbol [Internet]. España: Wanceulen Editorial Deportiva S.L.; 2013 [cited 2020 Mar 19]. Available from: https://bit.ly/33 Cksxl

[16] Vélez-Meza E, Guzmán-Terán A， Gallegos-Varela M, Méndez-.Urresta J. Digital Gamification in Basic General Education Students. Adv Intell Syst Comput [Internet]. 2020; (1110): 143-56. Available from: https://doi.org/10.1007/97 8-3-030-37221-7

[17] Pérez-Muñoz, Salvador; Domínguez-Muñoz, Rafael; Arenas-García, Javier; Barroso-García, Carlos; Pereira J. Iniciación Deportiva a través de las tareas jugadas: Una propuesta horizontal [Internet]. España: Wanceulen Editorial Deportiva S.L.; 2017 [cited 2020 Mar 19]. Available from: https://bit.ly/3dgBtS0

[18] Fusté-Masuet X. Juegos de iniciación a los deportes colectivos [Internet]. España: Paidotribo; 2019 [cited 2020 Mar 19]. Available from: https://bit.ly/3a0LL6S

[19] Orduño-Castro, Renán; s Valenzuela-Robles, Vianey; Romero-Romero I. Impacto del nivel de psicomotricidad en la iniciación deportiva al volibol en alumnos de 11 y 12 años. 3, 4 y 5 de Diciembre de 2019. In: Congreso Internacional Ejercicio Físico y Salud [Internet]. México: Centro de las Artes, Universidad de Sonora; 2019 [cited 2020 Mar 19]. Available from: https://bit.ly/33yRVJe

[20] Eduarte-Águila L, Stable-Bernal Y, Lanza-Bravo A. The professionals of the sport and the teaching -learning process at school in the stage of initiation of basketball from the physical education dimension. Conrado [Internet]. 2019 [cited 2020 Mar 19];15(66):156-62. Available from: https://bit.ly/33wWbZp

[21] Arronte-Mesa, Jorge; Ferro-Gozález B. El proceso de iniciación deportiva escolar en voleibol: una mirada de renovación para su aprendizaje. Pod - Rev Cienc y Tecnol en la Cult Física [Internet]. 2020 [cited 2020 Mar 19];15(1):127-41. Available from: https://bit.ly/3abAlNW

[22] Howells K, Wellard I, Woolf-May K. Young children's physical activity levels in primary (elementary) schools: what impact does physical education lessons have for young children? Early Child Dev Care. 2020 Apr 3;190(5):766-77.

[23] Bores-García D, Marín Rojas A, Méndez-Domínguez C, Mijarra-Murillo, Juan; Delfa-De La Morena J. Aspectos metodológicos clave para la formación de futuros maestros de Educación Física Subjectivities of bodies View project Pedagogical approaches in physical education View project. Retos [Internet]. 2020 [cited 2020 Mar 19];37(37):572-8. Available from: www.retos.org

[24] Ramón-Suárez G, Hoyos-Rodríguez G, Echeverri-Ramos J, Jiménez-Trujillo J, Ramírez-Silva W. Aprendizaje motor, precisión y toma de decisiones en el deporte [Internet]. Colombia: Universidad de Antioquia; 2013 [cited 2020 Mar 19]. Available from: https://bit.ly/2xeWaNC

[25] Fuentes-Guerra, Javier; Saenz-López, Pedro; Díaz-Trillo M. Educar a través del deporte [Internet]. España: Servicio de Publicaciones de la Universidad de Huelva; 2016 [cited 2020 Mar 19]. Available from: https://bit.ly/2QqKH4z

[26] Castejón-Oliva, Francisco; Giménez Fuentes-Guerra, Francisco; Jiménez Jiménez, Francisco López -Ros V. Investigación en formación deportiva [Internet]. España: Wanceulen Editorial Deportiva S.L; 2013 [cited 2020 Mar 19]. Available from: https://bit.ly/3a5ajfd

[27] Jozami S. Potenciando tu mente deportiva: Neurociencia simple para transformar el rendimiento deportivo [Internet]. España: CALIGRAMA; 2020 [cited 2020 Mar 19]. Available from: https://bit.ly/3bhM9ON

[28] Muñoz-Arroyave, Verónica; Lavega-Burgués, Pere; Costes, Antoni; Damian, Sabrine; Serna J. Los juegos motores como recurso pedagógico para favorecer la afectividad desde la educación física. Retos [Internet]. 2020 [cited 2020 Mar 19]; 38(38):166-72. Available from: https://bit.ly/2Wv SzWe 
[29] Gallardo-López J. Teorías del juego como recurso educativo. In: IV Congreso Virtual Internacional sobre Innovación Pedagógica y Praxis Educativa [Internet]. INNOVAGOGÍA; 2018 [cited 2020 Mar 19]. Available from: https://bit.ly/394csq5

[30] Everley S, Everley K. Primary school children's experiences of physical activity: the place of social and cultural capital in participation and implications for schools. Early Child Dev Care. 2019 Oct 15;189(12):2032-42.

[31] Wanceulen, J.; Wanceulen A. Fútbol: cuadernos técnicos $\mathrm{N}^{\mathrm{o}}$ 27. España: Wanceulen Editorial Deportiva, SL; 2016.

[32] Sánchez-Latorre D. Manual para el Entrenador de Fútbol Base [Internet]. España: Wanceulen Editorial Deportiva S.L; 2017 [cited 2020 Mar 19]. Available from: https://bit.ly/2J1LlBj

[33] Blazquez-Sanchez D. Iniciación a los deportes de equipo: del juego al deporte: de los 6 a los 10 años. España: INDE; 2013.

[34] Castejón-Oliva, Francisco; Díaz del Cueto, Mario; Giménez Fuentes-Guerra, Francisco; Jiménez-Jiménez, Francisco; López-Roz, Víctor; Vizcarra-Morales M. Deporte y enseñanza comprensiva [Internet]. España: Wanceulen Editorial Deportiva S.L.; 2010 [cited 2020 Mar 20]. Available from: https://bit.ly/2WwxjzK

[35] Omeñaca-Cilla, Raúl; Ruiz-Omeñaca J. Juegos cooperativos y educación física [Internet]. España: Paidotribo; 2019 [cited 2020 Mar 20]. Available from: https://bit.ly/2vHs9G6

[36] Gallardo-Vázquez, Pedro; Fernández-Gavira J. El Juego como recurso didáctico en Educación Física [Internet]. España: Wanceulen Editorial Deportiva S.L.; 2017 [cited 2020 Mar 20]. Available from: https://bit.ly/3a7hpQ5

[37] Humble S. Quantitative analysis of questionnaires: techniques to explore structures and relationships [Internet].
New York: Routledge; 2020 [cited 2020 Jun 14]. 216 p. Available from: https://bit.ly/3hr6uF9

[38] Urbano-Arévalo F, Mancha-Triguero D, Gómez-Carmona C, Gamonales J. Influence of coach profile in the training tasks design in football. A study cases. A study cases. Retos [Internet]. 2020 [cited 2020 Jun 20];38:204-12. Available from: www.retos.org

[39] Martínez-Merino N, Nabaskues-Lasheras I, Fernandez-Lasa U, Usabiaga-Arruabarrena O. Assessment of a school sport program in Usurbil: A critical perspective. Rev española Educ Física y Deport -REEFD [Internet]. 2019 [cited 2020 Jun 20];(426):395-403. Available from: http://www.reefd.es/index.php/reefd/article/viewFile/806/6 84

[40] Rodríguez-Verdura H, Lara-Caveda D, Rodríguez-Soriano C. The professor in sports initiation and the evaluation of his performance. Lect Educ Física y Deport [Internet]. 2018 [cited 2020 Jun 21];22(237):1-9. Available from: https://bit.ly/3hKnpm5

[41] Eduarte-Águila L, Stable-Bernal Y, Hernández Rivero M. Scientific-technological factors in the training process in sports initiation. Conrado [Internet]. 2019 [cited 2020 Jun 20]; 15(suppl.1):91-9. Available from: https://bit.ly/3dy6Y WE

[42] Volodymyr-Ivanovych, N. Characterization of the four-stage structure of the process of learning motor actions in sports games. International Journal of Human Movement and Sports Sciences, 7(4): 81-88, 2019. DOI: 10.13189/saj.2019.070403

[43] Nur Alyaa Athirah Roslan, Borhannudin Abdullah, "Differences in the Level of Children Gross Motor Skills Development in Silat, Taekwondo and Karate in Malaysia," International Journal of Human Movement and Sports Sciences, 8(2): $57 \quad-\quad 62, \quad 2020 . \quad$ DOI: $10.13189 /$ saj.2020.080202 